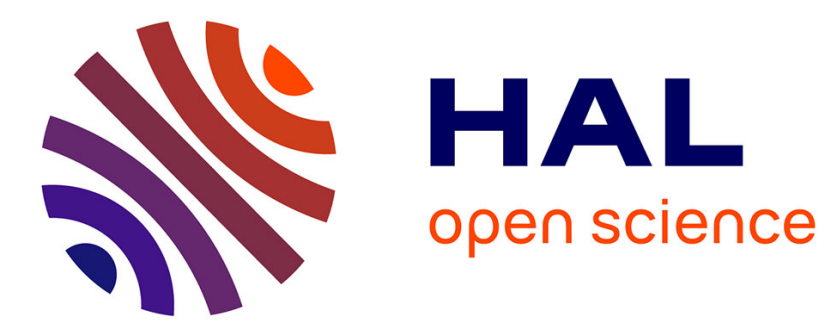

\title{
Remote sensing for groundwater modelling in large semiarid areas: Lake Chad Basin, Africa
}

Marc Leblanc, Guillaume Favreau, Sarah Tweed, Christian Leduc, Moumtaz Razack, Linus Mofor

\section{- To cite this version:}

Marc Leblanc, Guillaume Favreau, Sarah Tweed, Christian Leduc, Moumtaz Razack, et al.. Remote sensing for groundwater modelling in large semiarid areas: Lake Chad Basin, Africa. Hydrogeology Journal, 2007, 15 (1), pp.97-100. 10.1007/s10040-006-0126-0 . ird-00164820

\section{HAL Id: ird-00164820 \\ https://hal.ird.fr/ird-00164820}

Submitted on 23 Jul 2007

HAL is a multi-disciplinary open access archive for the deposit and dissemination of scientific research documents, whether they are published or not. The documents may come from teaching and research institutions in France or abroad, or from public or private research centers.
L'archive ouverte pluridisciplinaire HAL, est destinée au dépôt et à la diffusion de documents scientifiques de niveau recherche, publiés ou non, émanant des établissements d'enseignement et de recherche français ou étrangers, des laboratoires publics ou privés. 
Remote sensing for groundwater modelling in large semiarid areas: Lake Chad Basin, Africa

Marc Leblanc, Guillaume Favreau, Sarah Tweed, Christian Leduc, Moumtaz Razack, Linus Mofor

Hydrogeology Journal, Volume 15, Number 1, February 2007

pp. $97-100$

the original publication is available at www.springerlink.com 


\title{
Remote sensing for groundwater modelling in large semiarid areas: Lake Chad Basin, Africa
}

\author{
Marc Leblanc ${ }^{a}$, Guillaume Favreau ${ }^{b}$, Sarah Tweed $^{a}$, Christian Leduc ${ }^{b}$, \\ Moumtaz Razack ${ }^{c}$, Linus Mofor ${ }^{\mathrm{d}}$
}

a School of Geosciences, Monash University, Melbourne, Vic. 3800, Australia marc.leblanc@jcu.edu.au

b IRD, Maison des Sciences de I'Eau, 300, avenue E. Jeanbrau, 34095 Montpellier cedex 5, France

c University of Poitiers, 40 avenue du Recteur Pineau, 86022 Poitiers Cedex, France

${ }^{d}$ School of Technology, University of Glamorgan, Pontypridd CF37 1DL, UK

Keywords Satellite imagery, Numerical modelling, Groundwater recharge, Groundwater/surface water interaction, Geographic Information System 


\section{Introduction and Background}

Regional groundwater modelling studies in large semiarid regions are often hampered by field data scarcity, in both space and time. In such a case, remote sensing can offer complementary datasets and guide further investigations (e.g., Jackson 2002; Brunner et al. 2004; Schmid et al. 2005). Presented here is an example of how remote sensing and geographic information system (GIS) techniques have helped regional groundwater modelling through a better definition of groundwater recharge and discharge areas, groundwater/surface water interaction, and palaeohydrological settings. The work focuses on the Quaternary unconfined aquifer covering $500,000 \mathrm{~km}^{2}$ in the central part of the Lake Chad Basin in north-central Africa. It is shared between Chad, Niger, Nigeria and Cameroon and provides fresh water for the majority of $\sim 20$ million inhabitants of the basin (Fig. 1). Quaternary sediments form a continuous layer made up of fluvio-lacustrine deposits and aeolian sands, isolated from underlying aquifers by a thick layer of Pliocene clay. The regional aridity may be illustrated by environmental conditions to the north of Lake Chad where the annual rainfall is lower than $200 \mathrm{~mm}$ and the population density does not exceed 0.05 inhabitants per $\mathrm{km}^{2}$. Previous reliable hydrogeological studies are few, most of them dealing with the southern half of the aquifer. Regional syntheses can be found, for instance, in Leblanc (2002) and Gaultier (2004). The Quaternary aquifer has large natural piezometric depressions, vast closed concentric sinks also called 'hollow aquifers'. Major piezometric depressions have an amplitude of about $40 \mathrm{~m}$ and are found in SE Niger, central Chad, and NE Nigeria. The Quaternary aquifer interacts with the changing environment (climate, surface water and human activities). Understanding such a dynamic system and effective

management of this vast groundwater resource underpins the need for a groundwater model of the Quaternary aquifer. Such a model requires good 
spatio-temporal definition of processes indicative of land surface and aquifer interactions.

\section{Groundwater model}

The finite-difference groundwater model MODFLOW96 (USGS 1996) was used with the Groundwater Modelling System (GMS) pre- and post-processor. The Quaternary aquifer grid had a single layer, with cells ranging from 100 to 400 $\mathrm{km}^{2}$, depending on the observed hydraulic gradients. The flow exchanged with other aquifers on the lateral borders were represented using the MODFLOW Well package, and groundwater/surface water interaction with the MODFLOW River package (one dimensional conductance). The input data required by the model included: aquifer geometry; lateral flow with bordering aquifers; pumping rates; time series of the river and lake levels; time series of lake area; recharge and discharge zones; initial piezometry. A series of parameters (transmissivities, lake/river conductances, recharge and discharge rates) were adjusted during the calibration of the steady state of the 1960s and for the transient calibration between 1960 and 2000 (specific yield). The calibrated water table in steady state respected the patterns of the observed piezometry with a mean absolute head offset close to $8 \mathrm{~m}$. The calibrated transmissivities (min: $2.0 \mathrm{E}-04 \mathrm{~m}^{2} / \mathrm{s}$; mean: $1.2 \mathrm{E}-02 \mathrm{~m}^{2} / \mathrm{s}$; max: $8.5 \mathrm{E}-02 \mathrm{~m}^{2} / \mathrm{s}$ ) agreed well with the nature of the deposits and the values obtained from 111 pumping tests (min: $6.3 \mathrm{E}-05 \mathrm{~m}^{2} / \mathrm{s}$; mean: $8.0 \mathrm{E}-03 \mathrm{~m}^{2} / \mathrm{s}$; max: $7.0 \mathrm{E}-02 \mathrm{~m}^{2} / \mathrm{s}$ ). 


\section{Remote sensing data and processing techniques}

A variety of remote sensing data from multiple sensors were used: thermal (Meteosat, Advanced Very High Resolution Radiometer (AVHRR)), elevation (Shuttle Radar Topography Mission (SRTM)), optical (Moderate Resolution Imaging Spectroradiometer (MODIS), Landsat TM, AVHRR) and vegetation index (MODIS). They offered a range of spatial, temporal and spectral resolutions, and archive availability with ground resolution varying from $5 \mathrm{~km}$ (Meteosat) to $28.5 \mathrm{~m}$ (Landsat). Specific sensors were chosen according to the nature and the spatio-temporal variability of the object/process to detect. Remote sensors were used to detect large and rapidly changing objects such as the extent of the flood plains and Lake Chad (Meteosat, AVHRR), to much smaller features such as ponds and paleofeatures (Landsat). The period of study varied from single measurement (elevation with SRTM) to monthly measurements over several decades (Lake Chad fluctuations with Meteosat and AVHRR). The remote sensing and GIS techniques used were: (1) image enhancement (contrast stretching, principal component analysis (PCA), edge detection), image interpretation and terrain analysis (slope, volume) for the recognition of the paleohydrological setting, and (2) information extraction (threshold, unsupervised classification) for the mapping of recharge/discharge areas and groundwater/surface water interaction.

\section{Recharge and discharge areas mapping}

Geospatial techniques can be used in conjunction with groundwater modelling to define the space-time distribution of groundwater recharge and discharge (e.g. Lubczynski and Gurwin 2005). Within the Lake Chad Basin, the first models of the Quaternary aquifer (e.g. Leduc et al. 1998) incorporated only on-ground 
hydrogeological data and were, therefore, limited in regionalizing. In this study, satellite images were combined with hydrogeological data in a GIS to identify and map key surface indicators of recharge and discharge areas (Leblanc et al. 2003a; Leblanc et al. 2003b). This preliminary mapping was then imported into the steady-state groundwater model (Leblanc et al. 2003b). A wide range of recharge and discharge rates are cited in the literature for the Quaternary aquifer of the Lake Chad Basin (e.g. Leduc et al. 2000; Edmunds et al. 2002). The spatial distribution of recharge and discharge was imposed in the model according to the mapping described above, leaving the rates as the unknown parameter. Annual rates were then adjusted, within the range of literature values, by trial and error tests during the steady-state calibration. The combined used of the geospatial techniques and groundwater modelling thus improved knowledge of spatial distribution and intensity of recharge and discharge processes.

\section{Groundwater/surface water interaction}

The extent of Lake Chad is very sensitive to climate fluctuations, mainly because it is closed, shallow and in an arid environment. For example, it fluctuated from $25000 \mathrm{~km}^{2}$ and less than $6000 \mathrm{~km}^{2}$ between 1960 and 1990 (Lemoalle 2004). The Quaternary aquifer is interconnected with Lake Chad, and as a result, groundwater levels in the vicinity of Lake Chad have also declined in recent decades. Near the former northern lakeshore, groundwater levels (1980s-1990s) show a continuous water table decrease ranging from 0.2 to $0.9 \mathrm{~m} / \mathrm{yr}$. Satellite archives were used to reconstruct these fluctuations and were imported as input in the transient groundwater model. The first important fluctuations of Lake Chad for the second half of the twentieth century were recorded in Landsat data (Lemoalle, 1978). The current study complemented these Landsat data with monthly time series of AVHRR and Meteosat thermal images from 1986 to 2000 (1 and $5 \mathrm{~km}$ spatial resolution respectively). For many periods, AVHRR data 
were not available or affected by clouds. They were supplemented with Meteosat 30-day maximum value thermal composite data. Since the decrease in water level, floating vegetation has swamped large areas of Lake Chad. Thermal AVHRR and Meteosat data were used to map the extent of both open water and water under aquatic vegetation. Using the thermal satellite data, the high thermal inertia of open and covered waters can be distinguished from the relatively low thermal inertia of the surrounding bare dry land and non-aquatic vegetation (Rosema and Fiselier 1990; Leblanc et al. 2003b). The lake fluctuations data were stored in a GIS and pre-processed for input in the hydrogeological model. In areas where the lake dried up, the modeled groundwater/surface water relation stopped and evaporation rates were applied to the shallow groundwater. Simulated drawdowns are in rather good agreement with the field measurements.

\section{Paleohydrology}

Remote sensing data can help to map changes in surface water and/or environmental conditions that occurred in the past few decades. For longer periods, up to several thousands of years, regional climatic proxy data must be considered for constraining initial boundary conditions in groundwater models (e.g. Gossel et al. 2004). When large changes in surface water conditions may be expected, remote sensing data can also be used for delineating past river drainage patterns and/or past lake extents. In the Lake Chad Basin, Landsat TM and Modis data revealed the remains of ancient shorelines, rivers and deltas indicating the presence, during the early to middle Holocene, of a $340000 \mathrm{~km}^{2}$ paleo Megalake Chad, as far as the arid Sahara desert, where there is currently less than $100 \mathrm{~mm} / \mathrm{yr}$ of rainfall (Leblanc 2002; Leblanc et al. 2006a, b). Moreover, the SRTM data greatly enhanced knowledge of the topography in the desert area of the basin and allowed for an improved reconstruction of the 
$13000 \mathrm{~km}^{3}$ Megalake Chad (Leblanc et al. 2006b). Most of the Quaternary aquifer was then submerged and experienced a major recharge event. Environmental isotopic data $\left(\mathrm{A}^{14} \mathrm{C},{ }^{18} \mathrm{O},{ }^{2} \mathrm{H}\right)$ for groundwater in areas where current infiltration is low or nil (Leblanc et al. 2003a) also indicate that most of the Quaternary aquifer was then submerged and the last period of major recharge occurred during early to middle Holocene (e.g. Leduc et al. 2000). The current discharge area (in the Lowlands) of older groundwater from the confined aquifers of the basin (Edmunds et al. 1999) was then largely submerged beneath up to $160 \mathrm{~m}$ of lake water.

\section{Discussion}

The Quaternary aquifer could be considered as an extreme case. According to ordinary criteria, its size and extent, and the limited data set, should deter any attempt at groundwater modelling. However, in spite of appearances, the hydrogeological context was favourable. The large closed piezometric depressions that exist in different places around Lake Chad constitute severe hydraulic constraints. In natural conditions, such singularities are only explained by evapotranspiration of groundwater, obviously very small when it affects the water table at a depth greater than $40 \mathrm{~m}$. To preserve the regional head equilibrium in the groundwater model implies that horizontal flow are also very small. A step-by-step reconstruction of the groundwater flows is then possible. New remote-sensing applications for the Lake Chad Basin and the Quaternary aquifer are now being investigated. Satellite altimetry (Topex/Poseidon) was successfully applied to monitor water levels in the southern pool of Lake Chad (Birkett 2000). Future research could include detailed monitoring of the water budget of Lake Chad in both north and south pools by combining satellite altimetry (European Remote Sensing (ERS) and Envisat) and evapotranspiration mapping using energy balance algorithms such as SEBS (surface energy balance system; Su 2006). Such a detailed water budget could provide 
information on some of the scientific issues related to Lake Chad: groundwater seepage, seasonality and dynamics, and salt budget. Another prospective research theme is mapping forest cover change in the basin and the study of its impact on the water resources. The piezometric depressions in this region and recent works in a neighbouring region of the Sahel (Leduc et al. 2001) highlighted the importance of the tree cover on the local hydrological cycle. In the Lake Chad Basin a time-series of aerial photographs, SPOT and Landsat images are being used to assess the impact of deep-rooted trees and deforestation on the Quaternary aquifer. Radar imaging is a powerful tool for the reconstruction of arid land palaeohydrology because of its capability to penetrate dry surfaces in contrast with optical sensors (e.g. Robinson et al. 2006). A series of radar images are currently being used to map sub-surface paleodrainage in the Saharan part of the Lake Chad Basin. This could yield important information for the modelling of Megalake Chad and long-term modelling of the Quaternary aquifer.

\section{Conclusion}

The integration of remote sensing data in the groundwater model significantly improved water resource assessment in the Lake Chad Basin. The most important result was certainly the delineation and estimation of recharge and discharge, including some of the key parameters controlling the occurrence of large piezometric depressions. Satellite data used for groundwater/surface water interaction modelling provided information on the affects of short-term climate fluctuations on groundwater. Transient groundwater modelling revealed that the impact on the water table of the shrinkage of Lake Chad is strong, but limited in space to a relatively small area around the lake. The hydrodynamics of the system has been considerably modified since early Holocene. The delineation of Megalake Chad and paleorivers using remote sensing data can be used to define initial boundary conditions for the early to middle Holocene period, to describe 
the creation of piezometric depressions and to identify the sensitivity of the aquifer to major climate changes.

\section{References}

Birkett CM (2000) Synergistic Remote Sensing of Lake Chad: Variability of Basin Inundation. Remote Sens. Environ. 72: 218-236.

Brunner P, Bauer P, Eugster M, Kinzelbach W (2004) Using remote sensing to regionalize local precipitation recharge rates obtained from the chloride method. J. of Hydrology 294: 241-250.

Edmunds WM, Fellman E, Goni IB (1999) Lakes, groundwater and palaeohydrology in the Sahel of NE Nigeria: evidence from hydrogeochemistry. Journal of the Geological Society of London 156(2): 345-355.

Edmunds WM, Fellman E, Goni IB, Prudhomme C (2002) Spatial and temporal distribution of groundwater recharge in northern Nigeria. Hydrogeol. J. 10(1):205-215.

Gaultier G (2004) Recharge et paléorecharge d'une nappe libre en milieu sahélien (Niger oriental): Approches géochimique et hydrodynamique. PhD Thesis, School of Earth Sciences, University of Paris-Sud, Orsay, France.

Gossel W, Ebraheem AM, Wycisk P (2004) A very large scale GIS-based groundwater flow model for the Nubian sandstone aquifer in Eastern Sahara (Egypt, northern Sudan and eastern Libya). Hydrogeology Journal 12: 698-713

Jackson TJ (2002) Remote sensing of soil moisture: implications for groundwater recharge. Hydrogeology Journal 10(1): 40-51.

Leblanc M (2002) The use of remote sensing and GIS for water resources management of large semi-arid regions: a case study of the Lake Chad 
Basin, Africa. PhD Thesis, School of Technology, University of Glamorgan, UK and School of Geosciences, Poitiers University, France.

Leblanc M, Razack M, Dagorne D, Mofor L, Jones C (2003a), Application of

Meteosat thermal data to map soil infiltrability in the central part of the Lake Chad basin, Africa., Geophys. Res. Lett., 30(19), 1998. doi:10.1029/2003GL018094.

Leblanc M, Leduc C, Razack M, Lemoalle J, Dagorne D, Mofor L (2003b) Application of remote sensing and GIS for groundwater modelling of large semiarid areas: example of the Lake Chad Basin, Africa. In: Servat E, Najem W, Leduc C, Shakeel A (eds) Hydrology of Mediterranean and Semiarid Regions. IAHS Publ. 278, IAHS Press, Wallingford, UK. 186192.

Leblanc M, Leduc C, Stagnitti F, van Oevelen PJ, Jones C, Mofor L, Razack M, Favreau G (2006a). Evidence for Megalake Chad, north-central Africa, during the late Quaternary from satellite data. Palaeogeogr. Palaeoclimatol. Palaeoecol. 230: 230-242.

Leblanc M, Favreau G, Maley J, Nazoumou Y, Leduc C, Stagnitti F, van Oevelen PJ, Delclaux F, Lemoalle J (2006b). Reconstruction of Megalake Chad using Shuttle Radar Topographic Mission data. Palaeogeogr. Palaeoclimatol. Palaeoecol. 239:16-27

Leduc C, Salifou O, Leblanc, M (1998) Evolution des ressources en eau dans le département de Diffa (bassin du Lac Tchad, sud-est nigérien). In: Servat E, Hughes D, Fritsch JM, Hulme M (eds) Water Resources Variability in Africa during the 20th Century. IAHS Publ. 252, IAHS Press, Wallingford, UK. 281-288.

Leduc C, Sabljak S, Taupin JD, Marlin C, Favreau G (2000) Recharge of the Quaternary water table in the northwestern Lake Chad basin (southeastern Niger) estimated from isotopes. C. R. Acad. Sci., Paris Ila 330(5): 355-361. 
Leduc C, Favreau G, Schroeter P (2001) Long-term rise in a Sahelian watertable: the Continental Terminal in South-West Niger. Journal of Hydrology 243:43-54.

Lemoalle J (1978) Application des images Landsat à la courbe bathymétrique du lac Tchad. Cahiers ORSTOM, Série Hydrobiologie, 12(1): 83-87.

Lemoalle J (2004) Lake Chad: a changing environment. In: Nihoul JCJ, Zavialov PO, Micklin PP (eds) Dying and Dead Seas: Climatic versus Anthropic Causes. Proceedings of the NATO advanced workshop on dying and dead seas, May 2003, Liege, Belgium. NATO Science Series VI, Earth and environmental sciences. Kluwer Academic Publishers, Dordrecht 36: 321-329.

Lubczynski MW, Gurwin J (2005) Integration of various data sources for transient groundwater modeling with spatio-temporally variable fluxes - Sardon study case, Spain. Journal of Hydrology 306: 71-96.

Robinson CA, El-Baz F, Al-Saud TSM, Jeon SB (2006) Use of radar data to delineate palaeodrainage leading to the Kufra Oasis in the eastern Sahara. Journal of African Earth Sciences 44(2): 229-240.

Rosema A, Fiselier JL, (1990) Meteosat-based evapotranspiration and thermal inertia mapping for monitoring transgression in the Lake Chad region and Niger Delta. International Journal of Remote Sensing 11(5): 741-752.

Schmid T, Koch M, Gumuzzio J, (2005) Multisensor approach to determine changes of wetland characteristics in semiarid environments (central Spain) IEEE Transactions on Geoscience and Remote Sensing 43(11): 2516 - 2525. doi: 10.1109/TGRS.2005.852082.

Su ZB (2006) Estimation of the Surface Energy Balance. In: Anderson M (ed.) Encyclopedia of Hydrological Sciences. John Wiley \& Sons. Part 5. Remote Sensing. doi: 10.1002/0470848944.hsa068

USGS (1996) User's Documentation for MODFLOW-96, an update to the U.S. Geological Survey Modular Finite-Difference Ground-Water Flow Model. Open-File Report 96-485, USGS, Reston, Virginia. 
Figure 1 - Location of the Quaternary aquifer of the Lake Chad basin and paleohydrology of Megalake Chad. The potentiometric contours of the Quaternary aquifer are defined according to a series of technical reports from the 1970 s to the 1990s compiled in Leblanc (2002). They show large piezometric depressions (-). Megalake Chad was detected and mapped using SRTM 30, Landsat and Modis data (Leblanc 2002; Leblanc et al. 2006a, b).

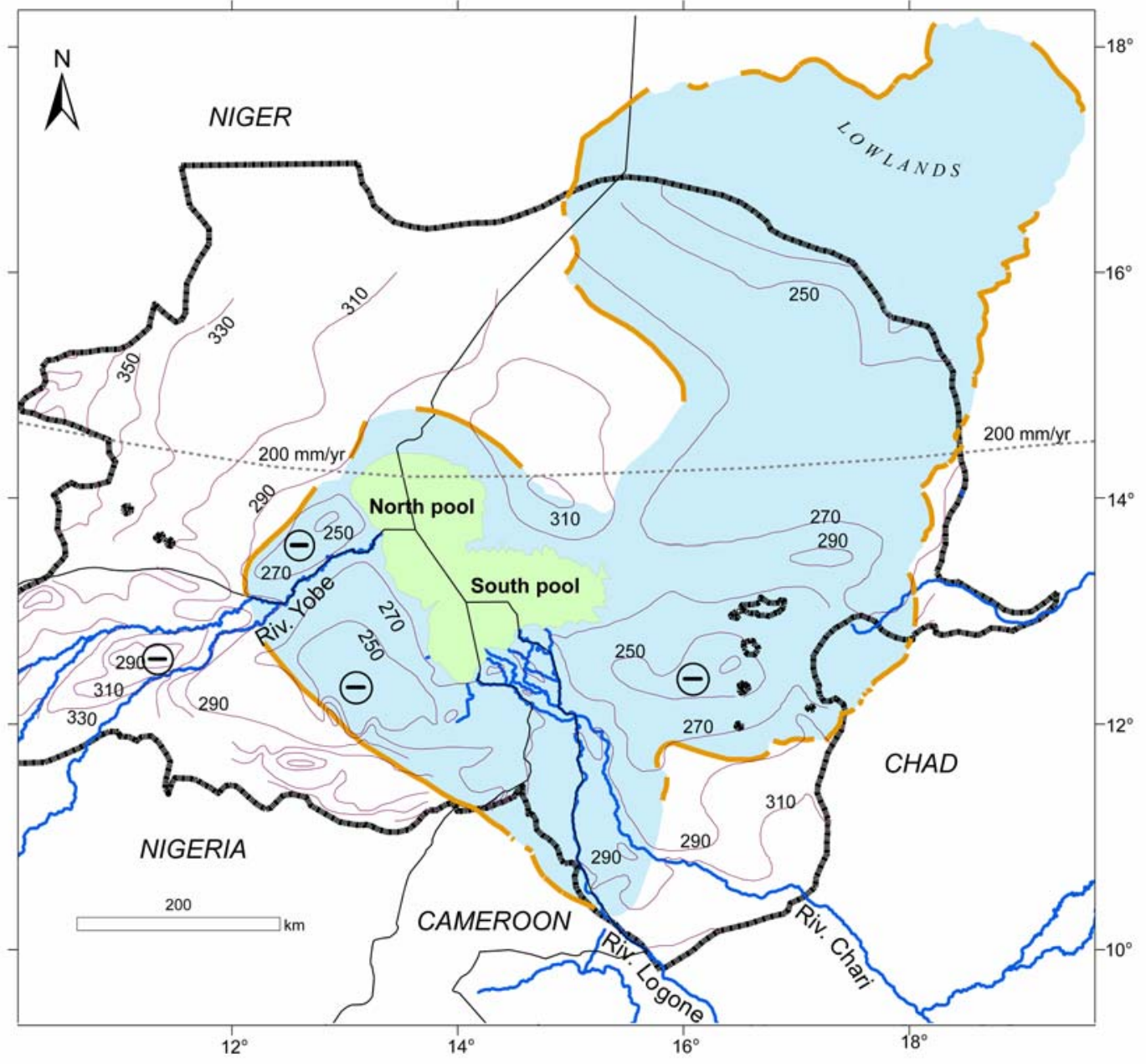

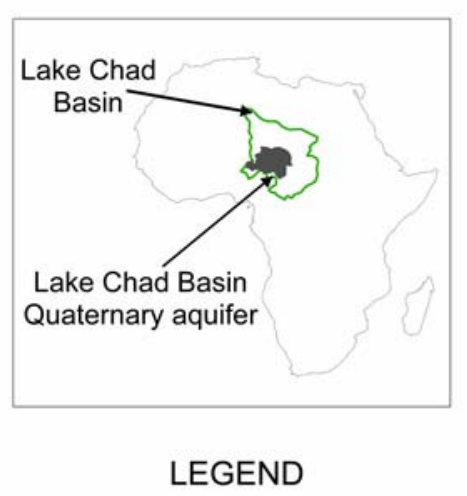

$200 \mathrm{~mm} / \mathrm{yr}$ isohyet (1951-1989)

Main rivers

Quaternary aquifer of the Lake Chad Basin

Potentiometric contours of the Quaternary aquifer

Main piezometric depressions

Megalake Chad paleoshoreline, detected with Landsat data (Leblanc et al., 2006a)

Megalake Chad highstand at $325 \mathrm{~m}$ amsl (Leblanc et al., 2006b)

'Large' Lake Chad at $283.5 \mathrm{~m}$ amsl (Lemoalle, 2004) 